University of Nebraska - Lincoln

DigitalCommons@University of Nebraska - Lincoln

Publications from USDA-ARS / UNL Faculty

U.S. Department of Agriculture: Agricultural

Research Service, Lincoln, Nebraska

March 1996

\title{
Planting Date and Residue Rate Effects on Growth, Partitioning, and Yield of Corn
}

Stephan Swanson

University of Nebraska-Lincoln, sswanson1@unl.edu

Wallace Wilhelm

University of Nebraska-Lincoln, wwilhelm1@unl.edu

Follow this and additional works at: https://digitalcommons.unl.edu/usdaarsfacpub

Part of the Agricultural Science Commons

Swanson, Stephan and Wilhelm, Wallace, "Planting Date and Residue Rate Effects on Growth, Partitioning, and Yield of Corn" (1996). Publications from USDA-ARS / UNL Faculty. 88.

https://digitalcommons.unl.edu/usdaarsfacpub/88

This Article is brought to you for free and open access by the U.S. Department of Agriculture: Agricultural Research Service, Lincoln, Nebraska at DigitalCommons@University of Nebraska - Lincoln. It has been accepted for inclusion in Publications from USDA-ARS / UNL Faculty by an authorized administrator of DigitalCommons@University of Nebraska - Lincoln. 


\title{
Planting Date and Residue Rate Effects on Growth, Partitioning, and Yield of Corn
}

\author{
Stephan P. Swanson and Wallace W. Wilhelm*
}

\begin{abstract}
Corn (Zea mays $\mathrm{L}$.) growth has been shown to be affected by planting date and amount of residue on the soil surface. The objective of this study was to determine if the adverse effects of cool soil temperatures on early seedling growth often associated with surface residues can be overcome by planting at later dates. Corn was planted at several planting dates (late April through early June) into soil that had residue applied at rates of $0,33,66$, and $100 \%$ of that produced by the previous crop. In general, spring-applied residue rates had little effect on measured plant responses. Planting corn before or after the optimum date resulted in reduced leaf area index, leaf area duration, total dry matter production, and grain yield. Maximum yield was achieved by planting corn about 10 May (near Lincoln, NE), regardless of the amount of residue applied in the spring. Yield declined with earlier or later planting dates: yield declined more rapidly when planting was delayed than when planting was advanced. Results indicate that, with spring residue application, planting date recommendations can be made independent of residue conditions.
\end{abstract}

S.P. Swanson, Dep. of Agronomy, 108 Keim Hall, and W.W. Wilhelm, USDAARS, 117 Keim Hall, Univ. of Nebraska, Lincoln, NE 68583-0934. Joint contribution of the USDA-ARS and the Agric. Res. Div. of the Univ. of Nebraska. Published as Journal Series no. 11180. Received 9 Jan. 1995. *Corresponding author (Email: wwilhelm@unl.edu).

Published in Agron. J. 88:205-210 (1996).
OORN PRODUCTION using tillage systems that leave more plant residues on the soil surface to reduce runoff and control wind and water erosion has increased in recent years. The U.S. Food Security Act of 1985 and the Food, Agriculture, Conservation, and Trade Act of 1990 require producers to limit runoff and erosion to specified levels if they participate in government commodity programs. Maintaining increased amounts of surface residues has been a major mechanism for producers to comply with these regulations.

Production systems that maintain surface residues can affect soil temperature, soil water, and many other soil physical, chemical, and biological properties that may, in turn, influence grain production. Allmaras et al. (1964), Willis et al. (1957), and van Wijk et al. (1959) observed that corn planted into residue covered soil generally had delayed emergence and reduced early seedling growth compared with corn planted into soil with no residue cover. These effects have been attributed to the cooler, wetter soil associated with the presence of surface residues. In a dry environment, the season-long water conservation

Abbreviations: EDM, ear dry matter; GDD, growing degree day; LAD, leaf area duration; LAI, leaf area index; LDM, leaf dry matter; SDM, stem dry matter; TDM, total dry matter. 
and temperature mediation attributes of surface residues resulted in increased grain yields (Wilhelm et al., 1986). However, the negative impact of cool soil temperatures early in the season may limit the benefits from midseason water conservation. Delaying the planting date until soil conditions are nearer the optimum for early plant development and growth may be a management strategy useful in overcoming these problems (Herbek et al., 1986).

Research conducted under uniform residue conditions has shown that corn planted earlier than normal for the region can produce yield equal to or greater than corn planted later than normal (Grogan et al., 1959; Helms et al., 1968; Pendleton and Egli, 1969). More recent research (Nafziger, 1994) has shown accelerating decline in yield as planting date is advanced or delayed from the optimum. These conclusions were based on normal or optimum planting dates for a single tillage or residue management practice. Eckert (1984) and Imholte and Carter (1987) found similar optimum planting dates for corn grown under conventional tillage (buried residues) and no-till (surface residue) systems in Wisconsin and Ohio, respectively. Conversely, Herbek et al. (1986) reported the optimum planting date for no-till (surface residue) to be 2 wk later than for conventional tillage (buried residue) in the poorly drained soils of Kentucky. Our objective was to determine the influence of planting date and spring residue application rate on growth, partitioning of dry matter, and yield of corn.

\section{MATERIALS AND METHODS}

The experiment was conducted in 1986 and 1987 at the University of Nebraska-Lincoln Agronomy Research Farm near Lincoln, NE, on a Crete-Butler silty clay loam (fine, montmorillonitic, mesic Pachic Argiustoll-Abruptic Argiaquoll) with 1 to $2 \%$ slope. Two sites (about $50 \mathrm{~m}$ apart) were selected for the study, one had been cropped to no-till corn for the previous $6 \mathrm{yr}$ and the other to soybean [Glycine max (L.) Merr.] for the previous 3 yr with disk as the primary tillage. Rainfed corn was planted at four planting dates (Table 1) and in four residue application rates $(0,33,66$, and $100 \% \mathrm{w} / \mathrm{w})$. Each of the treatment combinations was assigned to an experimental unit $4.6 \mathrm{~m}$ wide (6 rows) by $12.2 \mathrm{~m}$ long. Experimental units were arranged in a randomized block design with four complete blocks, two blocks within each site. Rows 1 and 6 on each plot provided a border (two rows) to minimize the impact of adjacent treatments.

During 1986, plot preparation consisted of cutting residue from the previous crop and removing it by hand raking approximately $2 \mathrm{wk}$ prior to each planting date. Plots were disked and corn residue was applied to the soil surface at rates of 0,1100 , 2200 , and $3300 \mathrm{~kg} \mathrm{ha}^{-1}$ for all planting dates for the $0,33,66$, and $100 \%$ treatments, respectively. During 1987 , residue from the previous corn crop was cut and removed by hand about $2 \mathrm{wk}$ prior to each planting date. Plots were disked and the collected corn residue applied at appropriate rates. Weight of residue applied within a planting date was based on the weight of residue produced the previous season on the $100 \%$ residue treatment. The $100 \%$ treatment received 2130,2430 , and $2020 \mathrm{~kg}$ $\mathrm{ha}^{-1}$ residue for the first, second, and fourth planting dates, respectively, during 1987 (excessive rain prevented the third planting date in 1987, which thus was deleted from the analyses). The fraction of ground cover (measured by determining if residue was present on 300 random points within each plot) was $0.13,0.39,0.81$, and 0.93 for the $0,33,66$, and $100 \%$ residue rate treatments, respectively, in 1986 and $0.12,0.39,0.82$, and
Table 1. Planting and dry matter harvest dates and stages during the 1986 and 1987 corn growing seasons in Nebraska.

\begin{tabular}{|c|c|c|c|c|c|}
\hline $\begin{array}{l}\text { Planting } \\
\text { treatment }\end{array}$ & $\begin{array}{l}\text { Planting } \\
\text { date }\end{array}$ & $\begin{array}{c}\text { Harvest } \\
\text { stage }\end{array}$ & $\begin{array}{c}\text { Harvest } \\
\text { date }\end{array}$ & $\begin{array}{c}\text { Days } \\
\text { after } \\
\text { planting }\end{array}$ & $\begin{array}{c}\text { GDD } \\
\text { after } \\
\text { planting } \dagger\end{array}$ \\
\hline \multicolumn{6}{|c|}{$\underline{1986}$} \\
\hline 1 (early) & 2 May & $\begin{array}{l}\text { 4-leaf } \\
\text { 8-leaf } \\
\text { 16-leaf }\end{array}$ & $\begin{array}{l}29 \text { May } \\
23 \text { June } \\
16 \text { July }\end{array}$ & $\begin{array}{l}27 \\
52 \\
75\end{array}$ & $\begin{array}{l}212 \\
531 \\
862\end{array}$ \\
\hline 2 (normal) & 13 May & $\begin{array}{l}\text { 4-leaf } \\
\text { 8-leaf } \\
\text { 16-leaf }\end{array}$ & $\begin{array}{l}12 \text { June } \\
3 \text { July } \\
23 \text { July }\end{array}$ & $\begin{array}{l}31 \\
52 \\
71\end{array}$ & $\begin{array}{l}275 \\
574 \\
862\end{array}$ \\
\hline 3 (late) & 26 May & $\begin{array}{l}\text { 4-leaf } \\
\text { 8-leaf } \\
\text { 16-leaf }\end{array}$ & $\begin{array}{l}20 \text { June } \\
10 \text { July } \\
31 \text { July }\end{array}$ & $\begin{array}{l}25 \\
45 \\
66\end{array}$ & $\begin{array}{l}301 \\
582 \\
888\end{array}$ \\
\hline 4 (very late) & 9 June & $\begin{array}{l}\text { 4-leaf } \\
\text { 8-leaf } \\
\text { 16-leaf } \\
\quad 1987\end{array}$ & $\begin{array}{l}26 \text { June } \\
15 \text { July } \\
8 \text { Aug. }\end{array}$ & $\begin{array}{l}17 \\
36 \\
60\end{array}$ & $\begin{array}{l}231 \\
504 \\
822\end{array}$ \\
\hline 1 (early) & 28 Apr. & $\begin{array}{l}\text { 4-leaf } \\
\text { 8-leaf } \\
\text { 16-leaf }\end{array}$ & $\begin{array}{l}26 \text { May } \\
20 \text { June } \\
12 \text { July }\end{array}$ & $\begin{array}{l}28 \\
53 \\
75\end{array}$ & $\begin{array}{l}262 \\
584 \\
876\end{array}$ \\
\hline 2 (normal) & 12 May & $\begin{array}{l}\text { 4-leaf } \\
\text { 8-leaf } \\
\text { 16-leaf }\end{array}$ & $\begin{array}{l}11 \text { June } \\
1 \text { July } \\
19 \text { July }\end{array}$ & $\begin{array}{l}30 \\
50 \\
68\end{array}$ & $\begin{array}{l}326 \\
596 \\
846\end{array}$ \\
\hline 4 (very late) $\ddagger$ & 7 June & $\begin{array}{l}\text { 4-leaf } \\
\text { 8-leaf } \\
\text { 16-leaf }\end{array}$ & $\begin{array}{l}27 \text { June } \\
13 \text { July } \\
1 \text { Aug. }\end{array}$ & $\begin{array}{l}20 \\
36 \\
55\end{array}$ & $\begin{array}{l}278 \\
487 \\
795\end{array}$ \\
\hline
\end{tabular}

† GDD, growing degree days (base $10^{\circ} \mathrm{C}$ ).

$\ddagger$ Due to excessive rainfall, there was no third (late) planting in 1987 .

0.94 in 1987 . B73 $\times$ Mol7 corn was planted (with a Kinze' $7100-23$ planter) at a $5-\mathrm{cm}$ depth at a rate to obtain 45000 plants $\mathrm{ha}^{-1}$ at each planting date. Nitrogen was surface applied at 180 $\mathrm{kg} \mathrm{N} \mathrm{ha}{ }^{-1}$ in the form of $\mathrm{NH}_{4} \mathrm{NO}_{3}$ prior to plant emergence. Weeds were controlled with preemergence application of alachlor [2-chloro- $N$-(2,6-diethylphenyl)- $N$-(methoxymethyl)acetamide] at $0.76 \mathrm{~L} \mathrm{ha}^{-1}$ and cyanazine $\{2-[[4-$ chloro-6-(ethylamino)-1,3,5triazin-2-yl]amino]-2-methylpropanenitrile $\}$ at $0.38 \mathrm{~L} \mathrm{ha}^{-1}$ and postemergence application of atrazine [6-chloro- $N$-ethyl- $N^{\prime}$-(1methylethyl)-1,3,5-triazine-2,4-diamine] at $0.57 \mathrm{~L} \mathrm{ha}^{-1}$, bentazon [3-(1-methylethyl)-(1H)-2,1,3-benzothiadiazin-4(3H)-one 2,2-dioxide] at $0.19 \mathrm{~L} \mathrm{ha}^{-1}$, and crop oil at $0.38 \mathrm{~L} \mathrm{ha}^{-1}$.

Number of seedlings emerged, soil temperature (maximumminimum thermometers with the sensor placed in the seed row at a depth of $5 \mathrm{~cm}$ ), and plant development stage (Ritchie et al., 1986) were assessed two to three times per week. At the V4, V8, and V16 stages (Table 1), a total of eight plants was collected from Rows 2 and 5 (four from each row) of each plot to measure aboveground dry matter production and leaf area index (LAI). Plants were separated into stalks, blades of leaves with visible collars, and ears (only at V16 stage). Leaf area index and leaf, stem, ear, and total dry matter were determined. Dry mass of blades of immature leaves (collars not visible) and leaf sheaths were included with stem mass. Leaf area duration (LAD), the integral of the LAI vs. time curve, represents the total opportunity for the crop to assimilate $\mathrm{C}$ within a specified time interval (Watson, 1947), and was calculated as (Hunt, 1978)

$$
\mathrm{LAD}=\left[\left(\mathrm{LAI}_{1}+\mathrm{LAI}_{2}\right)\left(T_{2}-T_{1}\right)\right] / 2
$$

where $\mathrm{LAI}_{1}$ and $\mathrm{LAI}_{2}$ are the leaf area index at Time 1 and 2 $\left(T_{1}\right.$ and $T_{2}$ ).

In early October, after corn in all treatments had reached physiological maturity (R6 stage), ears were hand harvested from

\footnotetext{
${ }^{1}$ Mention of a trademark or proprietary product does not constitute endorsement by the authors, the University of Nebraska, or the USDA Agricultural Research Service.
} 

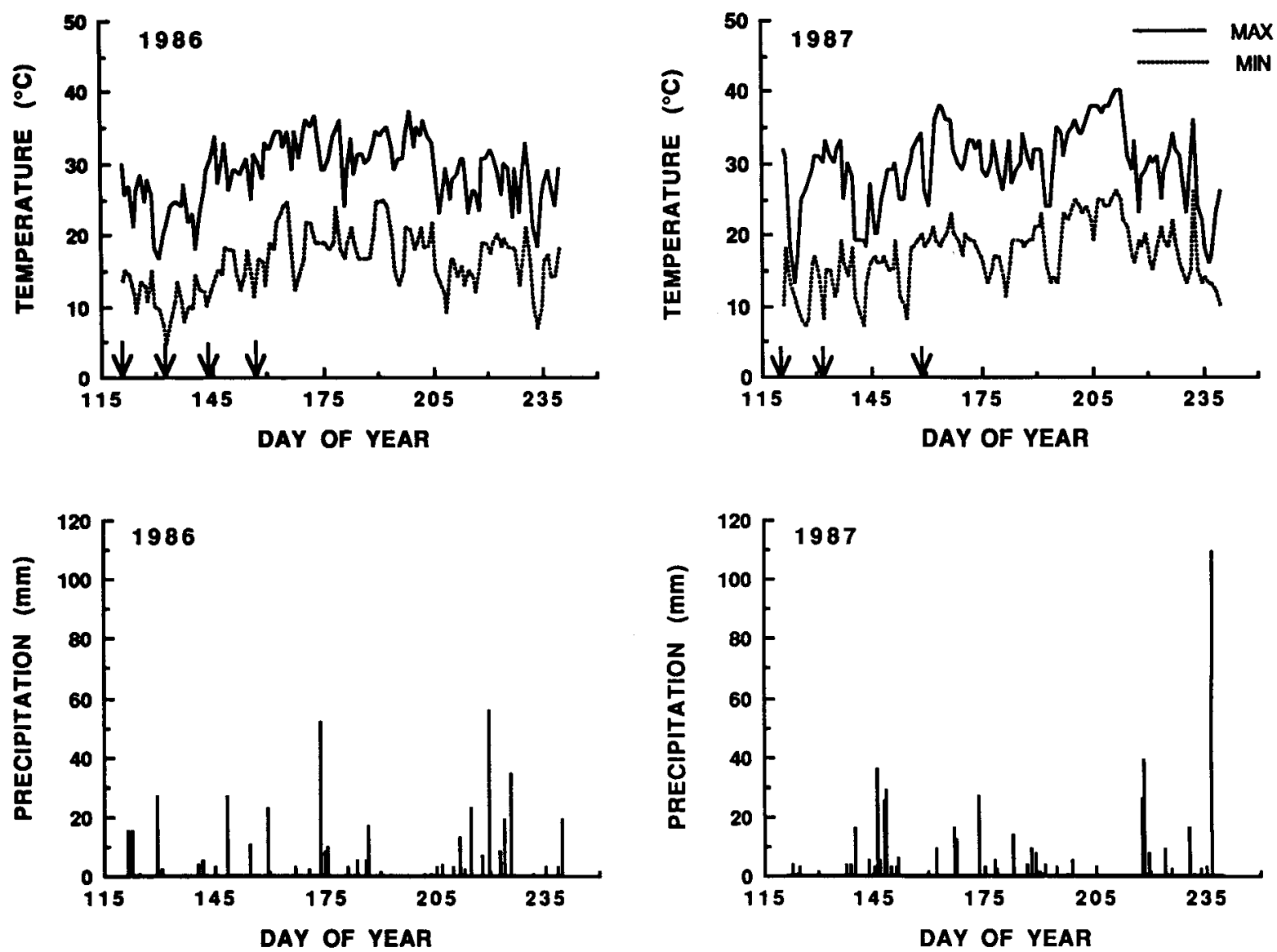

Fig. 1. Maximum and minimum air temperature and precipitation for 1986 and 1987 at the Agronomy Research Farm, Lincoln, NE. Arrows indicate planting dates (Table 1).

all plants in the two middle rows (12.2 $\mathrm{m}$ long) of all plots and grain yield and yield components determined. Grain yield reported at $0.155 \mathrm{~kg} \mathrm{~kg}^{-1}$ water content.

Air temperature and precipitation were recorded hourly at a weather station located about $1 \mathrm{~km}$ northeast of the research site. Growing degree days were calculated from daily maximum and minimum air temperatures as

$$
\mathrm{GDD}=\left[\left(T_{\max }+T_{\min }\right) / 2\right]-10
$$

where $T_{\max }=$ daily maximum (if $T_{\max }>30^{\circ} \mathrm{C}$, then $T_{\max }=$ $\left.30^{\circ} \mathrm{C}\right)$ and $T_{\min }=$ daily minimum $\left(T_{\min }<10^{\circ} \mathrm{C}\right.$, then $T_{\min }=$ $\left.10^{\circ} \mathrm{C}\right)$.

Data analyses were performed with the SAS computer package (SAS Institute, 1982). Each year, variances of data collected from the two sites were tested for homogeneity (Little and Hills, 1978) before data were combined for further evaluation. Analyses of variance and regression were used to evaluate treatment. Treatment sums of squares were partitioned into linear, quadratic, and cubic components to evaluate the nature of treatment responses. An alpha level of 0.05 was used in this report. Optimum dates of planting were calculated from quadratic functions fitted to response factor and time by least squares.

\section{RESULTS AND DISCUSSION}

Variances associated with data collected from the two sites were homogeneous and interactions between traits and sites were not significant. As a result data from the two sites could be combined for analysis. No planting date $x$ residue rate interactions were found for grain yield, yield components, dry matter production, or leaf area index; therefore, discussion will be restricted to main effects of planting date and residue rates. Maximum and minimum air temperature and precipitation at the site for the years 1986 and 1987 are shown in Fig. 1.

Table 2. Effect of planting date (averaged over residue rates) on grain yield and yield components of corn.

\begin{tabular}{|c|c|c|c|c|c|}
\hline \multirow[b]{2}{*}{ Trait } & \multicolumn{5}{|c|}{ Planting date $\nmid$} \\
\hline & 1 & 2 & 3 & 4 & Response $\neq$ \\
\hline & \multicolumn{5}{|c|}{1986} \\
\hline Yield, $\mathrm{Mg} \mathrm{ha}^{-1}$ & 6.95 & 7.10 & 5.73 & 3.32 & 0 \\
\hline Population, plants $\mathbf{m}^{-2}$ & 4.57 & 4.49 & 4.49 & 4.54 & NS \\
\hline Ear population, ears $\mathrm{m}^{-2}$ & 4.30 & 4.27 & 4.16 & 4.27 & NS \\
\hline Ears plant ${ }^{-1}$ & 0.94 & 0.94 & 0.93 & 0.95 & NS \\
\hline Kernels ear ${ }^{-1}$ & 626 & 634 & 533 & 304 & $Q$ \\
\hline Kernels plant $^{-1}$ & 587 & 598 & 494 & 285 & Q \\
\hline \multirow[t]{2}{*}{ Kernel weight, $\mathrm{g} \mathrm{m}^{-2}$} & 260 & 263 & 259 & 256 & NS \\
\hline & \multicolumn{5}{|c|}{1987} \\
\hline Yield, $\mathrm{Mg} \mathrm{ha}^{-1}$ & 6.31 & 6.64 & - & 4.50 & $\mathrm{Q}$ \\
\hline Population, plants $\mathrm{m}^{-2}$ & 4.57 & 4.60 & - & 4.49 & NS \\
\hline Ear population, ears $\mathbf{m}^{-2}$ & 4.35 & 4.40 & _- & 4.2 & NS \\
\hline Ears plant ${ }^{-1}$ & 0.95 & 0.96 & _- & 0.95 & NS \\
\hline Kernels ear ${ }^{-1}$ & 560 & 581 & _- & 413 & $\mathbf{Q}$ \\
\hline Kernels plant $^{-1}$ & 534 & 556 & _- & 393 & 0 \\
\hline Kernel weight, $\mathrm{g} \mathrm{m}^{-2}$ & 260 & 260 & - & 254 & Q \\
\hline
\end{tabular}

$\dagger 1$ (early) = 2 May 1986, 28 April 1987; 2 (normal) = 13 May 1986, 12 May 1987; 3 (late) = 26 May 1986 [no third planting in 1987]; 4 (very late) = 9 June 1986, 7 June 1987.

$\ddagger Q$, quadratic; NS, not significant at the 0.05 probability level. 
Table 3. Effect of residue rate (averaged over planting dates) on grain yield and yield components of corn.

\begin{tabular}{|c|c|c|c|c|c|}
\hline \multirow[b]{2}{*}{ Trait } & \multicolumn{5}{|c|}{ Residue rate } \\
\hline & $0 \%$ & $33 \%$ & $66 \%$ & $100 \%$ & Responset \\
\hline & \multicolumn{5}{|c|}{1986} \\
\hline Yield, $\mathrm{Mg} \mathrm{ha} \mathrm{a}^{-1}$ & 5.82 & 5.87 & 5.47 & 5.94 & NS \\
\hline Population, plants $\mathrm{m}^{-2}$ & 4.49 & 4.55 & 4.53 & 4.56 & NS \\
\hline Ear population, ears $\mathrm{m}^{-2}$ & 4.19 & 4.55 & 4.53 & 4.56 & NS \\
\hline Ears plant ${ }^{-1}$ & 0.93 & 0.95 & 0.94 & 0.93 & NS \\
\hline Kernels ear ${ }^{-1}$ & 534 & 529 & 499 & 535 & NS \\
\hline Kernels plant ${ }^{-1}$ & 498 & 499 & 468 & 499 & NS \\
\hline \multirow[t]{2}{*}{ Kernel weight, $\mathrm{g} \mathrm{m}^{-2}$} & 260 & 258 & 258 & 260 & NS \\
\hline & \multicolumn{5}{|c|}{1987} \\
\hline Yield, $\mathbf{M g}$ ha $^{-1}$ & 5.74 & 5.89 & $\overline{5.77}$ & 5.85 & NS \\
\hline Population, plants $\mathrm{m}^{-2}$ & 4.60 & 4.50 & 4.60 & 4.51 & NS \\
\hline Ear population, ears $\mathrm{m}^{-2}$ & 4.37 & 4.31 & 4.39 & 4.30 & NS \\
\hline Ears plant ${ }^{-1}$ & 0.95 & 0.96 & 0.95 & 0.95 & NS \\
\hline Kernels ear ${ }^{-1}$ & 508 & 531 & 508 & 526 & NS \\
\hline Kernels plant ${ }^{-1}$ & 484 & 509 & 484 & 501 & NS \\
\hline Kernel weight, $\mathrm{g} \mathrm{m}^{-2}$ & 258 & 257 & 258 & 259 & NS \\
\hline
\end{tabular}

$\uparrow$ NS, not significant at the 0.05 probability level.

\section{Grain Yields and Yield Components}

When averaged over residue rates, grain yield showed a quadratic response to planting date (Table 2). Predicted optimum planting date was 7 May in 1986, with a grain yield of $7.14 \mathrm{Mg} \mathrm{ha}^{-1}$, and 10 May in 1987 , with a yield of $6.71 \mathrm{Mg} \mathrm{ha}^{-1}$ (Table 2). When yield data from both years were combined, the predicted optimum planting date was 9 May. Kernels per ear and kernels per plant (Table 2) also showed quadratic responses to planting date during both seasons; however, kernel weight differed among planting dates in 1987 only. The date of planting that maximized these yield components ranged from 2 to 10 May, similar to that which maximized grain yield. Reduced levels of yield and yield components at the earlier planting dates may have been the result of lower soil temperatures, which slowed emergence, plant growth, and development. Cirilo and Andrade (1994) reported that early-planted corn had lower radiation use efficiency from emergence to silking compared with later-planted corn. Differences in radiation use efficiency among seedlings planted at different times may, in part, explain the reduced yield for corn planted before the optimum date.

Averaged across planting dates, residue rate did not affect yield or yield components (Table 3 ). These results differ from earlier findings at this location of increased yield with increased residue application (Wilhelm et al., 1986). Differences between results of these studies may be due to timing of residue treatment application. In the present study, residue treatments were applied 2 wk prior to planting instead of the previous fall as in the earlier work. In the current study, soil and residue conditions were identical for all treatments from time of harvest the previous fall until about 2 wk prior to planting, while different residue amounts were present all winter in the earlier work, and thus may have had greater effect on soil temperature, snow trapping, evaporation, and soil water. Differences in procedures and results between these two studies emphasize how differences in residue management can influence crop productivity.

\section{Plant Growth}

\section{Leaf Area Index}

As with grain yield, LAI showed a quadratic response to date of planting (Table 4), with maximum LAI values produced by planting at the second date. The greater LAI translated into greater LAD values as well (Table 4). Leaf area duration, a parameter that integrates the size and longevity of the crop canopy, was shown by Wilhelm et al. (1987) to be critical in determining yield potential of the crop. Low soil temperatures (Fig. 2) may have caused re-

Table 4. Effect of planting date (averaged over residue rates) on dry matter production during the 1986 and 1987 growing seasons.

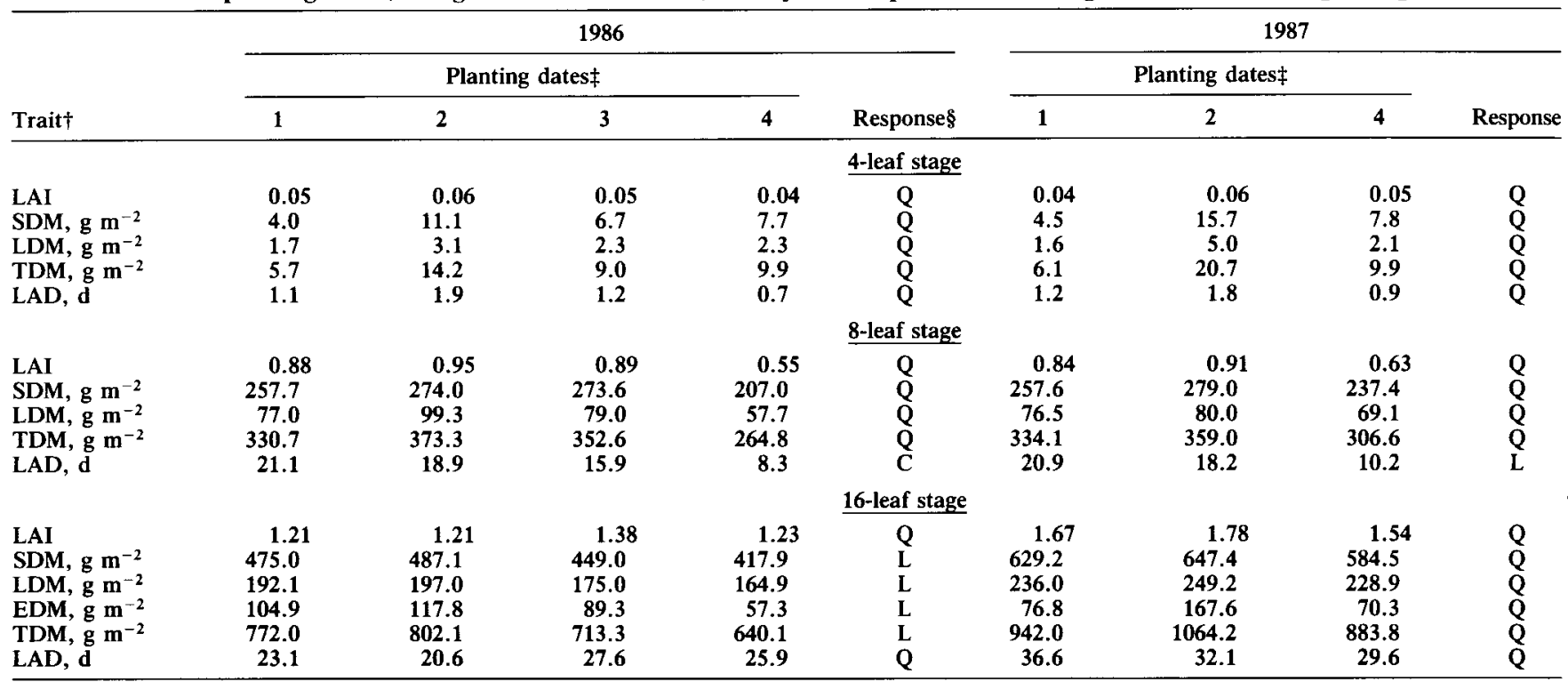

† EDM, ear dry matter; LAD, leaf area duration; LAI, leaf area index; LDM, leaf dry matter; SDM, stem dry matter; TDM, total dry matter.

$\doteqdot 1$ (early) = 2 May 1986, 28 April 1987; 2 (normal) = 13 May 1986, 12 May 1987; 3 (late) = 26 May 1986, no third planting in 1987; 4 (very late) = 9 June 1986, 7 June 1987.

\$ L, linear; $\mathrm{Q}$, quadratic; $\mathrm{C}$, cubic. 

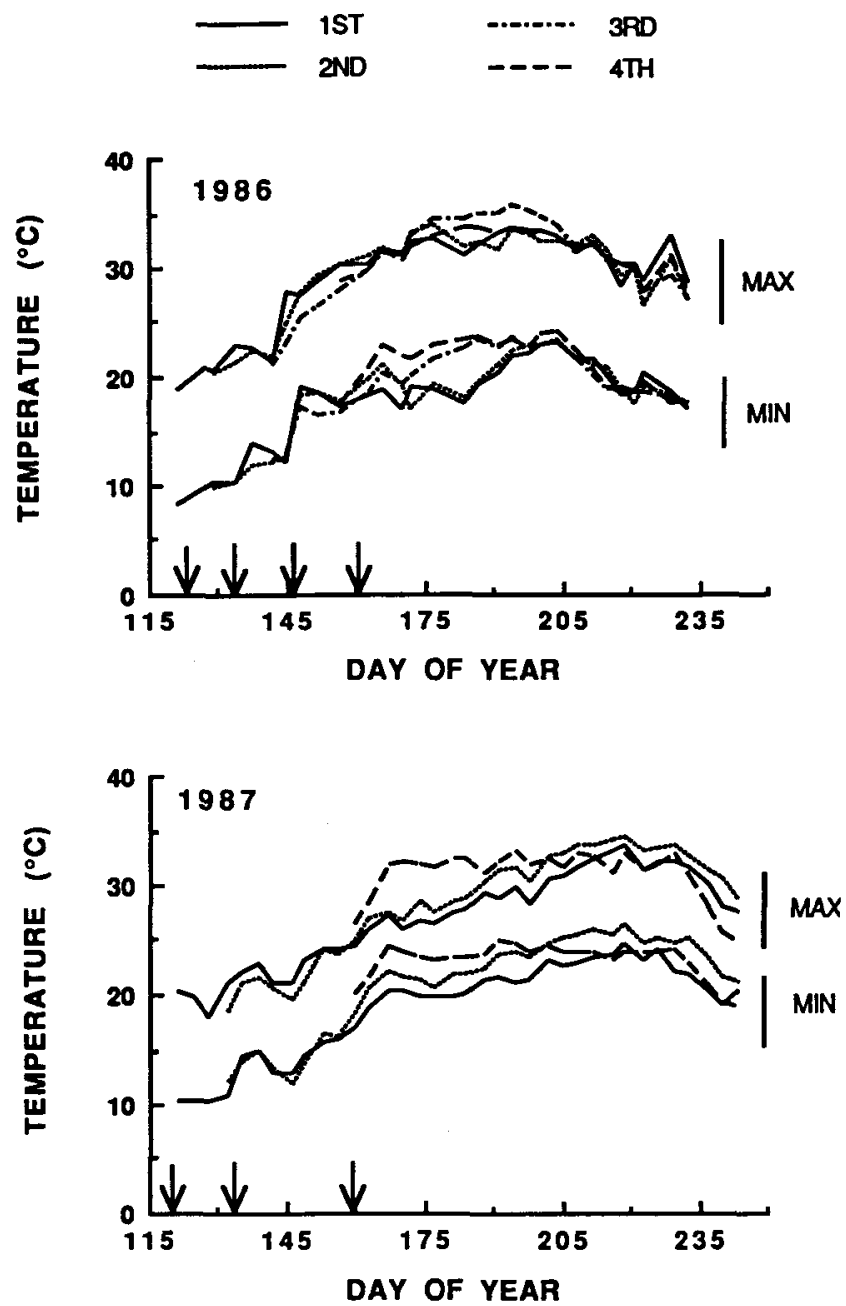

Fig. 2. Maximum and minimum soil temperature for corn planted at several dates during 1986 and 1987 . Arrows indicate planting dates (Table 1). Due to excessive rainfall, the third planting was not made in 1987 and data were omitted from analyses. duced LAI, and so also reduced LAD values for corn planted into soil with temperatures below the optimum for development.

Residue rate (Table 5) generally had less impact on LAI than date of planting (Table 4). Leaf area index increased with increased residue application rates at the 16-leaf stage in 1986, but showed a slight decrease with increased residue rates at the 8-leaf stage in 1987 (Table 5). Leaf area index did not differ among residue rate treatments at other sampling times.

\section{Dry Matter Production}

Total dry matter was greatest for corn planted on the second planting date during both growing seasons (Table 4). Stem, leaf, and ear dry matter were also greatest for corn planted at that time in both years (Table 4). Residue application rate (Table 5) had small and varied effects on partitioning of dry matter to plant components and total dry matter production.

Growth of corn planted on the first date may have been reduced at the V4 stage due to three factors: (i) soil temperatures below the optimum $\left(24-27^{\circ} \mathrm{C}\right.$; Walker, 1970) for emergence and early seedling growth, (ii) low leaf area duration, or (iii) lower radiation use efficiency (Cirilo and Andrade, 1994). Corn planted on the first date took $0.65 \mathrm{~d}(\approx 4 \mathrm{GDD})$ and $1.78 \mathrm{~d}(\approx 9 \mathrm{GDD})$ longer to reach $50 \%$ emergence than did corn planted on the second date in 1986 and 1987, respectively. Minimum and maximum soil temperatures were 9.3 and $20.0^{\circ} \mathrm{C}$, respectively, for 1986 and 11.2 and $20.2^{\circ} \mathrm{C}$, respectively, for 1987 for the corn planted at the first date (averaged across all residue treatments) for the period 1 to 15 May. The delay in emergence and lower soil temperatures (Fig. 2) reduced early plant growth and resulted in lower LAI and LAD. The possible influence of radiation use efficiency in this study was not determined.

Amount of spring-applied residue did not influence op-

Table 5. Effect of residue rate (averaged over planting dates) on dry matter production during the 1986 and 1987 growing seasons.

\begin{tabular}{|c|c|c|c|c|c|c|c|c|c|c|}
\hline \multirow[b]{3}{*}{ Trait $\dagger$} & \multicolumn{5}{|c|}{1986} & \multicolumn{5}{|c|}{1987} \\
\hline & \multicolumn{4}{|c|}{ Residue rate } & \multirow[b]{2}{*}{ Response } & \multicolumn{4}{|c|}{ Residue rate } & \multirow[b]{2}{*}{ Response } \\
\hline & $0 \%$ & $33 \%$ & $66 \%$ & $100 \%$ & & $0 \%$ & $33 \%$ & $66 \%$ & $100 \%$ & \\
\hline & \multicolumn{10}{|c|}{ 4-leaf stage } \\
\hline $\begin{array}{l}\text { SDM, g m } \mathbf{m}^{-2} \\
\text { LDM, g m } \\
\text { TDM, g m } \\
\text { LAD, d }\end{array}$ & $\begin{array}{l}6.9 \\
2.2 \\
9.1 \\
1.2\end{array}$ & $\begin{array}{r}8.2 \\
2.5 \\
10.8 \\
1.3\end{array}$ & $\begin{array}{l}6.9 \\
2.2 \\
9.2 \\
1.2\end{array}$ & $\begin{array}{l}7.3 \\
2.4 \\
9.7 \\
1.2\end{array}$ & $\begin{array}{c}\mathrm{C} \\
\mathrm{C} \\
\mathrm{C} \\
\mathrm{NS}\end{array}$ & $\begin{array}{r}10.1 \\
2.9 \\
13.0 \\
1.3\end{array}$ & $\begin{array}{r}9.4 \\
2.9 \\
12.3 \\
1.3\end{array}$ & $\begin{array}{r}9.4 \\
3.1 \\
12.5 \\
1.4\end{array}$ & $\begin{array}{r}8.4 \\
2.7 \\
11.2 \\
1.2\end{array}$ & $\begin{array}{c}\mathbf{L} \\
\mathbf{N S} \\
\mathbf{N S} \\
\mathrm{C}\end{array}$ \\
\hline & \multicolumn{10}{|c|}{ 8-leaf stage } \\
\hline $\begin{array}{l}\text { LAI } \\
\text { SDM, g m } \\
\text { LDM, } \mathrm{g} \mathrm{m}^{-2} \\
\text { TDM, g m} \\
\text { LAD, d }\end{array}$ & $\begin{array}{c}0.82 \\
262.5 \\
79.9 \\
342.5 \\
16.2\end{array}$ & $\begin{array}{c}0.81 \\
246.11 \\
76.2 \\
322.3 \\
15.9\end{array}$ & $\begin{array}{r}0.80 \\
250.5 \\
77.1 \\
327.7 \\
15.7\end{array}$ & $\begin{array}{c}0.84 \\
249.1 \\
79.7 \\
328.7 \\
16.5\end{array}$ & $\begin{array}{l}\text { NS } \\
\text { NS } \\
\text { NS } \\
\text { NS } \\
\text { NS }\end{array}$ & $\begin{array}{r}0.84 \\
274.5 \\
77.2 \\
351.7 \\
17.4\end{array}$ & $\begin{array}{r}0.81 \\
262.7 \\
75.6 \\
338.3 \\
16.7\end{array}$ & $\begin{array}{r}0.80 \\
251.2 \\
74.3 \\
325.5 \\
16.5\end{array}$ & $\begin{array}{r}0.73 \\
243.6 \\
73.7 \\
317.4 \\
15.2\end{array}$ & $\begin{array}{l}\mathbf{L} \\
\mathbf{L} \\
\mathbf{L} \\
\mathbf{L} \\
\mathbf{L}\end{array}$ \\
\hline LAD, d & \multicolumn{10}{|c|}{ 16-leaf stage } \\
\hline $\begin{array}{l}\text { SDM, g m } \\
\text { LDM, } \mathbf{g ~ m}^{-2} \\
\text { EDM, g m } \\
\text { TDM, g m } \\
\text { LAD, d }\end{array}$ & $\begin{array}{r}458.2 \\
183.1 \\
92.2 \\
733.5 \\
23.9\end{array}$ & $\begin{array}{r}434.8 \\
175.5 \\
89.0 \\
699.3 \\
23.1\end{array}$ & $\begin{array}{r}456.6 \\
182.3 \\
95.7 \\
734.5 \\
24.2\end{array}$ & $\begin{array}{r}479.4 \\
188.1 \\
92.5 \\
760.0 \\
26.0\end{array}$ & $\begin{array}{c}\text { Q } \\
\text { NS } \\
\text { NS } \\
\text { NS } \\
\text { Q }\end{array}$ & $\begin{array}{r}595.9 \\
230.0 \\
97.0 \\
922.8 \\
32.9\end{array}$ & $\begin{array}{r}639.7 \\
241.5 \\
112.3 \\
993.4 \\
32.9\end{array}$ & \begin{tabular}{r|}
621.3 \\
236.0 \\
105.1 \\
962.4 \\
32.6
\end{tabular} & \begin{tabular}{r|}
624.7 \\
244.7 \\
105.3 \\
974.7 \\
32.2
\end{tabular} & $\begin{array}{c}Q \\
L \\
\text { NS } \\
\text { C } \\
\text { NS }\end{array}$ \\
\hline
\end{tabular}

† EDM, ear dry matter; LAD, Leaf area duration; LAI, leaf area index; LDM, leaf dry matter; SDM, stem dry matter; TDM, total dry matter.

$\ddagger$ L, linear; $Q$, quadratic; $C$, cubic; NS, not significant at the 0.05 probability level. 

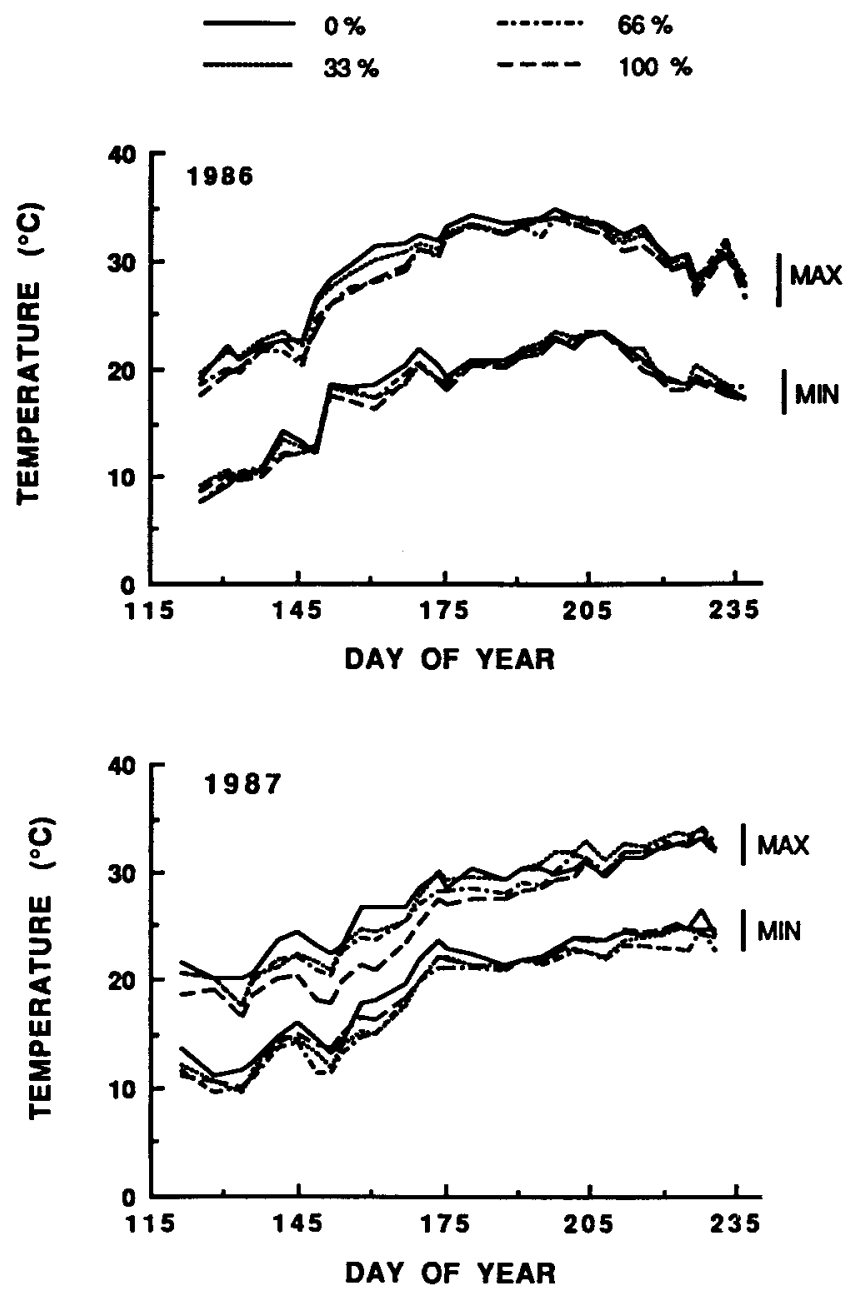

Fig. 3. Maximum and minimum soil temperature for corn planted into soil covered with several rates of residue during 1986 and 1987.

timum planting date, and had little effect on grain yield, yield components, leaf area index, and dry matter partitioning. This finding differs from the results of Wilhelm et al. (1986), who found increased yield with increased residue application rates under no-till. The short interval between residue application and planting $(2 \mathrm{wk})$ in the current study may not have allowed soil temperature and water differences between residue rate treatments to become established. These results do indicate that rates of development and growth and yield are greatest when corn is planted near the optimum time, regardless of cover, when the residue is spring applied. The contrasting findings of this and the previous experiment emphasize the importance of season-long residue management and understanding the impact residue management has on other management decisions. In this study, changing planting date (Fig. 2) had a much greater impact on soil temperature experienced by the germinating seed and emerging seedling than changing the residue rate (Fig. 3). Maximum temperature ranged about $5^{\circ} \mathrm{C}$ over the four residue rate treatments, while it ranged about $10^{\circ} \mathrm{C}$ among the planting dates.

Results of this study indicate grain yield and yield component values were greatest for corn planted near 9 May and decreased for either earlier or later planting. This result agrees with research by Johnson (1978) and Nafziger (1994), in that an optimum date of planting exists and that planting before or after that optimum date results in yield reduction. However, comparing the optimum date reported here with those found in the previous studies indicates that the optimum date depends on location and the tillage and residue management practices used in the production system. The predicted optimum date in the current study (7-10 May) is 5 to $10 \mathrm{~d}$ later than those reported by Johnson (1978) and Nafziger (1994). Herbek et al. (1968) reported that the optimum planting date with no-tillage (surface residues) was about $14 \mathrm{~d}$ later than with conventional tillage (buried residues). Nafziger (1994) also reported later predicted optimum dates of planting in the driest year of his study. Conditions of production in the current study (rainfed in eastern Nebraska) represent a dry environment for corn production.

\section{REFERENCES}

Allmaras, R.R., W.C. Burrows, and W.E. Larson. 1964. Early growth of corn as affected by soil temperature. Soil Sci. Soc. Am. Proc. 28:271-275.

Cirilo, A.G., and F.H. Andrade. 1994. Sowing date and maize productivity: I. Crop growth and dry matter partitioning. Crop Sci. 34: 1039-1043.

Eckert, D.J. 1984. Tillage system $\times$ planting date interactions in corn production. Agron. J. 62:760-761.

Grogan, C.O., M.S. Zuber, N. Brown, and D.C. Peters. 1959. Date of planting studies with corn. Mo. Agric. Exp. Stn. Res. Bull. 706.

Helms, J.L., V.L. Ferguson, and M.S. Zuber. 1968. Effect of date of planting on high-amylose corn. Agron. J. 60:530-531.

Herbek, J.H., V.L. Murdock, and R.L. Blevins. 1986. Tillage system and date of planting effects on yield of corn on soils with restricted drainage. Agron. J. 78:580-582.

Hunt, R. 1978. Plant growth analysis. Edward Arnold, London.

Imholte, A.A., and P.R. Carter. 1987. Planting date and tillage effects on corn following corn. Agron. J. 79:746-751.

Johnson, R.R. 1978. Considerations in replanting corn. p. 68-76. In Proc. Corn Sorghum Res. Conf., 33rd, Chicago. 12-14 Dec. Am. Seed Trade Assoc., Washington, DC.

Little, T.M., and F.J. Hills. 1978. Agricultural experimentation design and analysis. John Wiley \& Sons, New York.

Nafziger, E.D. 1994. Corn planting date and plant population. J. Prod. Agric. 7:59-62.

Pendleton, J.W., and D.B. Egli. 1969. Potential yield of corn as affected by planting date. Agron. J. 61:70-71.

Ritchie, S.W., J.J. Hanway, and G.O. Benson. 1986. How a corn plant develops. Rev. ed. Iowa State Univ. of Sci. and Technol.-Coop. Ext. Serv. Spec. Rep. 48.

SAS Institute. 1982. SAS user's guide. SAS Inst., Cary, NC.

van Wijk, W.R., W.E. Larson, and W.C. Burrows. 1959. Soil temperatures and the early growth of corn from mulched and unmulched soils. Soil Sci. Soc. Am. Proc. 23:428-434.

Walker, John M. 1970. One-degree increments in soil temperature affect maize seedling behavior. Soil Sci. Soc. Am. Proc. 33:729-736.

Watson, D.J. 1947. Comparative physiological studies on the growth of field crops: I. Variation in net assimilation rate and leaf area between species and varieties, and within and between years. Ann. Bot. (London) 11:41-76.

Wilhelm, W.W., J.W. Doran, and J.F. Power. 1986. Corn and soybean yield response to crop residue management under no-tillage production systems. Agron. J. 78:184-189.

Wilhelm, W.W., J.S. Schepers, L.N. Mielke, J.W. Doran, J.R. Ellis, and W.W. Stroup. 1987. Dryland maize development and yield resulting from tillage and nitrogen fertilization practices. Soil Tillage Res. 10:167-179.

Willis, W.O., W.E. Larson, and D. Kirkham. 1957. Corn growth as affected by soil temperature and mulch. Agron. J. 49:323-328. 